\title{
Identification and Characterization of a Freshwater Pyrococcus sp. Strain PK 5017 and Identification of Pfu-Like IS Elements in Thermococcus sibiricus MM 739
}

\author{
Wirojne Kanoksilapatham ${ }^{1}$, Patlada Pasomsup ${ }^{1}$, Maria C. Portillo ${ }^{2}$, Porranee Keawram ${ }^{1} \&$ Juan M. Gonzalez ${ }^{2}$ \\ ${ }^{1}$ Department of Microbiology, Faculty of Science, Silpakorn University, Nakhon Pathom, Thailand \\ 2 IRNAS-CSIC, Avda. Reina Mercedes 10, Sevilla, Spain \\ Correspondence: Wirojne Kanoksilapatham, Department of Microbiology, Faculty of Science, Silpakorn \\ University, Nakhon Pathom 73000, Thailand. Tel: 66-3427-3045 ext. 28805. E-mail: wirojne@su.ac.th
}

Received: June 3, 2012 Accepted: June 19, 2012 Online Published: August 22, 2012

doi:10.5539/ijb.v4n4p11 URL: http://dx.doi.org/10.5539/ijb.v4n4p11

The research is financed by the Scientific Promotion and Development Fund, Faculty of Science, Silpakorn University (RGI 2553-06) and Silpakorn University Research and Development Institute (SURDI 54/01/18 and SURDI 55/01/05). JMG and MCP acknowledge support from a CSIC movility program, PA1001993 and PA1002058, and the Andalusian Government Bio288 which included FEDER funds

\begin{abstract}
A strictly anaerobic, hyperthermophilic Pyrococcus sp. strain PK 5017 (PK 5017) was isolated from a freshwater hot spring in Thailand. Cells of strain PK 5017 are irregular cocci arranging singly and in pairs with a diameter range of $0.7-1.2 \mu \mathrm{m}$. Temperature, $\mathrm{pH}$ and $\mathrm{NaCl}$ concentration ranges for growth are $75-105{ }^{\circ} \mathrm{C}$ (opt. temp. $=$ 95-100 ${ }^{\circ} \mathrm{C}$ ), $\mathrm{pH} 5-7.8$ (opt. $\mathrm{pH}=7.2$ ) and 2.5-<40 g/l NaCl (opt. conc. $=24 \mathrm{~g} / \mathrm{l}$ ). Growths on the pancreatic digest of casein, yeast extract, peptone, meat extract, beef extract and skim milk ( $5 \mathrm{~g} / 1$ ea.) occur in $\mathrm{S}^{\mathrm{o}}$ containing media. Growths on maltose, trehalose, starch and xylitol occur in $\mathrm{S}^{\circ}$-free media. No growth occurs on dextrose, sucrose, xylose, sorbitol, mannose and cellobiose. $\mathrm{S}^{\mathrm{o}}$ is not obligatory for growth, but stimulates growth. $\mathrm{G}+\mathrm{C}$ content of genome is $42.5 \mathrm{~mol} \%$. DNA-DNA hybridization results reveal more similar genome sequence of strain PK 5017 to $P$. horikoshii than P. furiosus. Genome of strain PK 5017 contains multiple copies of the homologous IS-pfu of elements. Based on the biochemical characteristics and the presence of the homologous IS-pfus, strain PK 5017 is a close relative of $P$. furiosus. Two copies of IS-pfu homologs named "IS-pfu-Ts1" and "IS-pfu-Ts2" are identified in the complete genome sequence of Thermococcus sibiricus MM 739. Pyrococcus sp. strain PK 5017 = Pyrococcus sp. strain Pikanate $5017=$ JCM17043 = ATCC BAA-2246.
\end{abstract}

Keywords: hyperthermophile, thermococcales, pyrococcus, thermococcus, hot spring, archaea, IS element

\section{Introduction}

Pyrococcus species are hyperthermophilic archaea of the Order Thermococcales, growing by fermenting peptides and producing $\mathrm{H}_{2} \mathrm{~S}$ as an end product (Woese et al., 1990; Stetter, 1996; Adams, 1999). Elemental sulfur $\left(\mathrm{S}^{\circ}\right)$ appeared to stimulate, but is not obligatory for growths of many species belonging to the genera Thermococcus and Pyrococcus (Jannasch et al., 1992; Barbier et al., 1999; Miroshnichenko et al., 2001; Adams et al., 2001). However, $\mathrm{S}^{0}$ was reported to be an essential growth factor for T. gorgonarius and T. pacificus (Miroshnichenko et al., 1998). Pyrococcus furiosus, but not P. horikoshii, was found to utilize maltose in $\mathrm{S}^{\circ}$-free (Fiala and Stetter, 1986; Gonzalez et al., 1998).

In general, the reported range of optimal growth temperature of Pyrococcus spp. was $\geq 90^{\circ} \mathrm{C}$ (Fiala \& Stetter, 1986; Zillig et al., 1987; Erauso et al., 1993; Gonzalez et al., 1998; Barbier et al., 1999; Birrien et al., 2011). However, the optimum temperature reported on Pyrococcus sp. strain HT3 was $80-85^{\circ} \mathrm{C}$ (Kecha et al., 2007). The general reported range of optimum temperature for Thermococcus spp. was $<90^{\circ} \mathrm{C}$ (Neuner et al., 1990; Kobayashi et al., 1994; Huber et al., 1995; Cambon-Bonavita et al., 2003; Pikuta et al., 2007).

Most Pyrococcus spp. and Thermococcus spp., isolated from marine hydrothermal ecosystems, usually require approx. 20-30 g/l NaCl for optimal growths. T. zilligii and T. waiotapuensis, isolated from freshwater hot pool in New Zealand, showed their optimum concentrations of $<6 \mathrm{~g} / 1 \mathrm{NaCl}$ (Ronimus et al., 1997; Gonzalez et al., 
1999). A freshwater Pyrococcus sp. strain HT3 $(15-20 \mathrm{~g} / \mathrm{l} \mathrm{NaCl})$, isolated from a hot spring in Northeastern Algeria and T. sibilicus $(18-20 \mathrm{~g} / \mathrm{l} \mathrm{NaCl})$, isolated from a high salinity oil well in Western Siberia, showed their optimum concentrations close to those of marine isolates (Miroshnichenko et al., 2001; Kecha et al., 2007).

Repetitive IS elements have been proposed to be very useful to differentiate hyperthermophilic strains and to obtain additional insights on their phylogeny (Escobar-Páramo et al., 2005; White et al., 2008). Three types of homologous Pyrococcus furiosus-insertion sequences named IS-pfu-I, IS-pfu-II and IS-pfu-III were found abundantly in the complete genome sequence of P. furiosus DSM 3638 (AE009950) and other related Pyrococcus spp., which were isolated from the Mediterranean Sea (DiRuggiero et al., 2000; Kanoksilapatham et al., 2004; Escobar- Páramo et al., 2005). An inducible malEFG operon was previously demonstrated in a 17.8 kbp-long composite transposon (Tn) flanked by two copies of the IS-pfu-II in the genomes of P. furiosus and $T$. litoralis (AF307053) (DiRuggiero et al., 2000). On the other hand, IS-pfu-like sequence and the inducible malEFG homolog were not detected in the complete genome sequence of P. horikoshii OT3 (NC_000961), which was isolated from Okinawa Trough, North Pacific Ocean (Gonzalez et al., 1998; Maeder et al., 1999). Thermococcus sibiricus was isolated from a subterranean hot oil well in Western Siberia, Russia (Miroshnichenko et al., 2001). Complete genome sequence of T. sibiricus MM 739 (CP001463) is available in the NCBI public data base, and no IS-pfu homolog has been reported.

In this report, a freshwater Pyrococcus sp. strain PK 5017 was isolated and characterized based on polyphasic approaches including morphology, physiology, phylogenetic analysis, DNA properties and analysis of the IS-pfu sequences.

\section{Materials and Methods}

\subsection{Source Organisms and Culture Media}

Pyrococcus sp. strain PK 5017 was isolated during this study. Other hyperthermophilic archaea used in this study were Pyrococcus furiosus (DSM 3638) and P. horikoshii (DSM 12428).

A liter of PT medium was composed of $24 \mathrm{~g} \mathrm{NaCl}, 4 \mathrm{~g} \mathrm{Na}_{2} \mathrm{SO}_{4}, 0.7 \mathrm{~g} \mathrm{KCl}, 0.2 \mathrm{~g} \mathrm{NaHCO}_{3}, 0.1 \mathrm{~g} \mathrm{KBr}, 0.03 \mathrm{~g}$ $\mathrm{H}_{3} \mathrm{BO}_{3}, 10.8 \mathrm{~g} \mathrm{MgCl}_{2} \cdot 6 \mathrm{H}_{2} \mathrm{O}, 1.5 \mathrm{~g} \mathrm{CaCl}_{2} .2 \mathrm{H}_{2} \mathrm{O}, 0.025 \mathrm{~g} \mathrm{SrCl}_{2} \cdot 6 \mathrm{H}_{2} \mathrm{O}, 5 \mathrm{~g}$ pancreatic digest of casein (Criterion, USA), $1 \mathrm{~g}$ yeast extract, $1 \mathrm{ml}$ resazurin solution $(0.2 \mathrm{~g} / \mathrm{l}), 3 \mathrm{ml} \mathrm{Na}_{2} \mathrm{~S} .9 \mathrm{H}_{2} \mathrm{O}$ solution $[25 \%(\mathrm{w} / \mathrm{v}), \mathrm{pH}$ 7], and 5-10 g elemental sulfur $\left(\mathrm{S}^{\circ}\right)$. $\mathrm{pH}$ was adjusted using $1 \mathrm{~N} \mathrm{NaCl}$ or $1 \mathrm{~N} \mathrm{HCl}$ before sterilization to $\mathrm{pH}$ 7.0-7.2 (Gonzalez et al., 1998). Sterilization was performed at $100{ }^{\circ} \mathrm{C}$ for $1 \mathrm{~h}$. This medium was employed to cultivate strain PK 5017, Pyrococcus furiosus (DSM 3638) and P. horikoshii (DSM 12428). Modified PT medium containing $10 \mathrm{~g} / 1$ $\mathrm{NaCl}$ was employed for enrichment and isolation. Low protein (LP) and high protein (HP) media were employed to study sulfur metabolism. A liter of the LP medium contains similar compositions to the PT medium, except containing $0.5 \mathrm{~g} / \mathrm{lg}$ pancreatic digest of casein and $0.2 \mathrm{~g} / 1$ yeast extract. A liter of the HP medium contains similar compositions to the PT medium, except containing $0.2 \mathrm{~g} / \mathrm{l}$ yeast extract.

\subsection{Sample Collection and Isolation}

Sediment samples were collected near thermal sources of Pong Duet Hot Spring, Huai Nam Dang National Park $\left(19^{\circ} 14^{\prime} \mathrm{N}, 98^{\circ} 41^{\prime} \mathrm{E}\right)$, Northern Thailand. Approximate temperature of $100^{\circ} \mathrm{C}$ was measured at the sampling sites. The sediments were transported to a laboratory in an ice bath. The sediments were inoculated into isolation medium in serum bottles, and they were incubated at $90^{\circ} \mathrm{C}$ for $24 \mathrm{~h}$. Positive cultures were observed and screened using a phase contrast microscope. A positive culture containing coccus was subcultured to a new medium until stable. Isolation of pure culture was performed using serially tube dilution technique for triplicate times. A pure culture named "strain PK 5017" was obtained and stored in PT medium at $4^{\circ} \mathrm{C}$.

\subsection{Scanning Electron Microscopy}

Cells of strain PK 5017 obtained from an overnight culture were washed using 0.1 M phosphate buffer, pH 7.4. The washed cell pellet was fixed using $2.5 \%$ glutaraldehyde in $0.1 \mathrm{M}$ phosphate buffer, $\mathrm{pH}$ 7.4. The fixed cell pellet was washed again and serially dehydrated using 30,50,70,90, 95 and 100\% ethanol. The dehydrated cells were coated with Au. The grid was scanned using a Cam Scan MX 2000.

\subsection{Determining for Growth Conditions}

Growth kinetics on temperature was studied in PT medium $(10 \mathrm{~g} / \mathrm{l} \mathrm{NaCl}, \mathrm{pH}$ 7.2). Growth kinetics on $\mathrm{NaCl}$ requirement was studied at $95^{\circ} \mathrm{C}$ in modified PT media (1-43 g/l NaCl, $\mathrm{pH}$ 7.2). Growth kinetics on $\mathrm{pH}$ was studied in PT medium $(24 \mathrm{~g} / 1 \mathrm{NaCl})$ at $95^{\circ} \mathrm{C}$. $\mathrm{pH}$ of the medium were adjusted to a pH range of 5-7.5 using $1 \mathrm{~N}$ $\mathrm{HCl}$ or $1 \mathrm{~N} \mathrm{NaOH}$ at room temperature before sterilization. Cultures were grown in serum bottles containing 100 $\mathrm{ml}$ media, and samples $(1 \mathrm{ml})$ were drawn at an appropriate time interval $(1-2 \mathrm{~h})$ during exponential phase of growth $(0-10 \mathrm{~h})$. Cell numbers were counted using a Neubauer counting chamber $(0.1 \mathrm{~mm}$ depth) and a phase 
contrast microscope. Specific growth rate constants $(\mu)$ were estimated from the regression lines resulting from plotting at least four data points.

\subsection{Comparative Growth Kinetics}

Growth rates of strain PK 5017, P. furiosus and P. horikoshii were compared at 3 and $43 \mathrm{~g} / \mathrm{l} \mathrm{NaCl}$, the concentrations around the minimum and maximum limits. Briefly, overnight cultures were diluted 100 times using appropriate media, and immediately inoculated (to obtain an approx. conc. of $10^{5} \mathrm{cells} / \mathrm{ml}$ ) into triplicate bottles of the prewarmed media. The cultures were incubated at $95^{\circ} \mathrm{C}$. Aliquots $(1 \mathrm{ml})$ were collected at $3 \mathrm{~h}$ interval, and cell numbers were counted under a phase contrast microscope.

\subsection{Nutritional Requirements}

Growth on protein substrates (pancreatic digest of casein, yeast extract, peptone, meat extract, beef extract and skim milk) at a final concentration of $5 \mathrm{~g} / 1$ was tested in a modified PT medium containing $0.2 \mathrm{~g} / 1$ yeast extract and $1 \mathrm{~g} / 1 \mathrm{~S}^{\circ}$. Growth on carbon sources (dextrose, maltose, sucrose, mannose, xylose, trehalose, glycerol, xylitol, D-sorbitol, starch and cellobiose) at a final concentration of $2 \mathrm{~g} / \mathrm{l}$ was tested in a $\mathrm{S}^{\mathrm{o}}$-free PT medium containing $0.5 \mathrm{~g} / \mathrm{l}$ of pancreatic digest of casein and $0.2 \mathrm{~g} / \mathrm{l}$ of yeast extract. Growth was monitored at $24 \mathrm{~h}$ from triplicate cultures using the direct count techniques.

\subsection{Sulfur Metabolism}

Strain PK 5017, P. furiosus and P. horikoshii were studied in LP $(0.5 \mathrm{~g} / 1$ of pancreatic digest of casein) and HP (5 $\mathrm{g} / \mathrm{l}$ of pancreatic digest of casein) media ( $\mathrm{pH} 7.2)$ with and without addition of maltose $(0,2$ and $5 \mathrm{~g} / \mathrm{l})$. All media contained $1 \mathrm{~g} / 1 \mathrm{~S}^{\circ}$, except if stated otherwise. The experiments were performed at $95^{\circ} \mathrm{C}$ in serum bottles containing $100 \mathrm{ml}$ media. Briefly, overnight cultures were diluted 100 times using appropriate media and inoculated (to obtain an approx. conc. of $10^{5} \mathrm{cell} / \mathrm{s} / \mathrm{ml}$ ) into triplicate bottles of the prewarmed media. Cells were counted at times 0 and $24 \mathrm{~h}$ using a phase contrast microscope.

\subsection{Genomic DNA Extraction and 16S rRNA Gene Analysis}

DNA was extracted from overnight cultures, following the method described by Charbonnier and Forterre (1995). 16S rRNA gene fragments were amplified using two archaeal specific primer pairs (DeLong, 1992). Nucleotide sequences of the primer pairs were 5' CTTTGA ATTCCG GTTGAT CCTGCC GGA 3' and 5' CGGCGT TGAATT CCAATT AAACCG CACGC 3', and GTGCCA GCMGCC GCGGTAA and 5' ACGGGC GGTGWG TRCAA 3'. PRC reactions were performed for 30 cycles of $1 \mathrm{~min}$ at $94^{\circ} \mathrm{C}, 1 \mathrm{~min}$ at $56^{\circ} \mathrm{C}$, and $1 \mathrm{~min}$ at $72^{\circ} \mathrm{C}$ followed standard PCR reactions. Amplified DNA was purified, using a Qiagen PCR Purification Kit (Qiagen, Chatsworth, Calif., USA). The purified PCR products were TA cloned into pCR 2.1 TOPO $^{\circledR}$ (Invitrogen, Carlsbag, Calif., USA). Plasmid DNA was extracted using the Qiagen Plasmid Miniprep Kit. DNA was sequenced twice from the cloned plasmids obtained.

\subsection{Detection of IS-pfu}

Nucleotide sequence of a primer specific to the inverted repeat (IR) sequence of the homologous IS-pfu of elements was 5' GATA CTGT TAGG ATA 3'. PCR reactions were performed for 30 cycles of 1 min at $94^{\circ} \mathrm{C}, 1$ min at $40^{\circ} \mathrm{C}$, and $1 \mathrm{~min}$ at $72^{\circ} \mathrm{C}$, following standard PCR reactions. Amplified DNA was purified and TA cloned into pCR 2.1 TOPO $^{\circledR}$. Plasmid DNA was extracted using the Qiagen Plasmid Miniprep Kit. DNA was sequenced twice from the cloned plasmids obtained.

\subsection{Phylogenetic Study}

Nucleotide sequences were aligned by Neighbor joining algorithm using CLUSTAL W (Thompson et al., 1994). Pairwise distances were computed using the program MEGA 5.05 (Tamura et al., 2011). Phylogenetic trees were constructed by setting a bootstrap value of 1000 .

\section{$2.11 G+C$ Content Analysis}

$\mathrm{G}+\mathrm{C}$ content of DNA was determined using melting temperature estimate (Marmur \& Doty, 1962). Increased absorbance at $260 \mathrm{~nm}$ was measured using a model T70 UV-VIS Spectrophotometer (PG Instruments Ltd). Reference $\mathrm{G}+\mathrm{C}$ contents of $P$. furiosus $(40.8 \mathrm{~mol} \%)$ and P. horikoshii $(41.9 \mathrm{~mol} \%)$ were analyzed from the complete genome sequence nos. AE009950 and NC_000961, respectively.

\subsection{DNA-DNA Hybridization}

DNA-DNA relatedness was estimated using the non-radioactive protocol described by Ziemke et al. (1998). Briefly, genomic DNA of the target strain was double labeled with DIG-11-dUTP and biotin-16-dUTP, using a nick-translation kit (Roche Diagnostics GmbH, Mannheim, Germany). Labeled DNA was mixed with an equal quantity of unlabeled DNA from the strain to be analyzed and denatured in a boiling water bath for 5 min. 
Hybridization of these genomic DNAs was carried out for $16 \mathrm{~h}$ at $64^{\circ} \mathrm{C}\left(30^{\circ} \mathrm{C}\right.$ below the melting temperature of DNA from the strain PK 5017). Single- and double-stranded DNAs were separated by elution from hydroxyapatite and separately distributed in streptavidin-coated microtiter plates. After incubation with anti-DIG antibodies conjugated with alkaline phosphatase (Roche), detection of DNA in each well was performed with $p$-nitrophenyl phosphate, following measurement of the color developed at $405 \mathrm{~nm}$. Homologous (strain PK5017) and heterologous DNA associations were processed simultaneously. The relative binding ratio of heterologous DNA was expressed as a percentage of homologous DNA binding.

\section{Results}

\subsection{Morphology and Identification}

Strain PK 5017 was isolated from a sediment sample described in Materials and methods. Observation using SEM revealed irregular cocci arranging singly and in pairs (Figure 1). A diameter range of 0.7-1.2 $\mu \mathrm{m}$ was determined. 16S rRNA gene was sequenced (GenBank FJ793195 and HQ223090). The sequences FJ793195 (885 nt. long) and HQ223090 (864 nt. long) contain 419 nt. overlapping. Phylogenetic analysis based on 16S rDNA sequences using reference sequences from the Order Thermococcales revealed that strain PK 5017 could be classified as a member of the genus Pyrococcus (Figure 2).

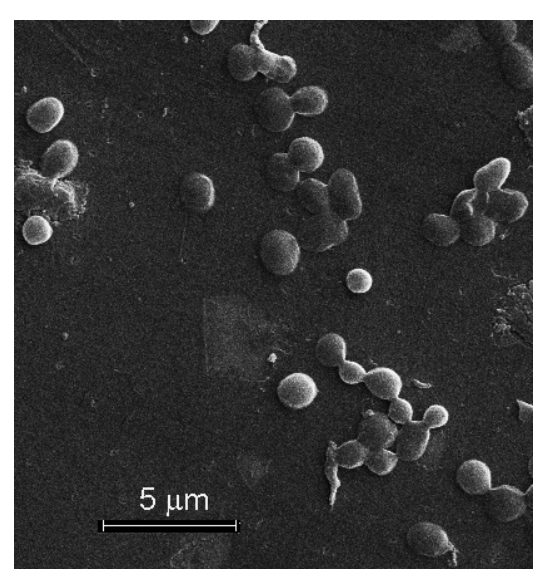

Figure 1. Scanning electron micrograph of strain PK 5017. Bar represents $5 \mu \mathrm{m}$

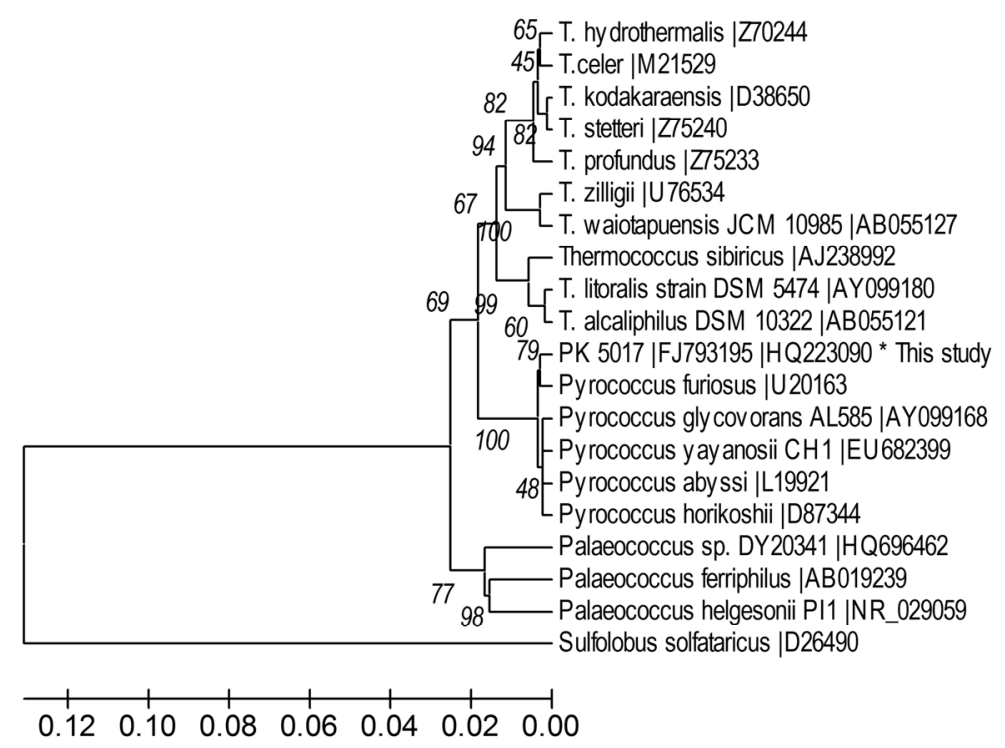

Figure 2. Phylogenetic tree based on 16S rDNA sequences of strain PK 5017 and other reference species belonging to the Order Thermococcales inferred by Neighbor joining algorithm. Alignment was performed by using CLUSTAL W. Pairwise distances were computed from a bootstrap score of 1000 using the program MEGA 5.05. The 16S rDNA sequence of Sulfolobus solfataricus (D26490) was employed as an out-group 


\subsection{G+C Base Composition and DNA-DNA Hybridization Analysis}

$\mathrm{G}+\mathrm{C}$ content of genome of strain PK 5017 is $42.5 \mathrm{~mol} \%$. This value was determined relative to $P$. furiosus (40.8 mol\%) and $P$. horikoshii (41.9 mol\%) under the same condition. DNA-DNA hybridization results revealed 78 and $44 \%$ similarities of strain PK 5017 to $P$. horikoshii and P. furiosus, respectively. Cross hybridization using $P$. horikoshii revealed $55 \%$ similarities to $P$. furiosus. These values were congruent with those previously reported by Gonzalez et al. (1998). The results indicate that genome sequence of strain PK 5017 and P. horikoshii shared the highest similarity, and both strains shared approx.50\% similarity to $P$. furiosus.

\subsection{Optimal Growth Condition}

Growths of strain PK 5017 at a temperature range of $75-105{ }^{\circ} \mathrm{C}$ (opt. temp. of $95-100{ }^{\circ} \mathrm{C}$ ), a pH range of 5-7.8 (opt. pH 7.2) and a $\mathrm{NaCl}$ concentration range of $2.5-<40 \mathrm{~g} / 1$ (opt. conc. of $24 \mathrm{~g} / 1 \mathrm{NaCl}$ ) were determined (Figures 3A-3C). At $\mathrm{pH} 5$, a slow growth rate was observed $\left(\mu=0.22 \mathrm{~h}^{-1}\right)$. No growth was detected at $\mathrm{pH}<5$ (Figure 3B). At $40 \mathrm{~g} / 1 \mathrm{NaCl}$, growth of strain PK 5017 was rarely detected $\left(\mu=0.05 \mathrm{~h}^{-1}\right)$. No growth was detectable at 1 and $>40 \mathrm{~g} / \mathrm{l} \mathrm{NaCl}$ (Figure 3C).
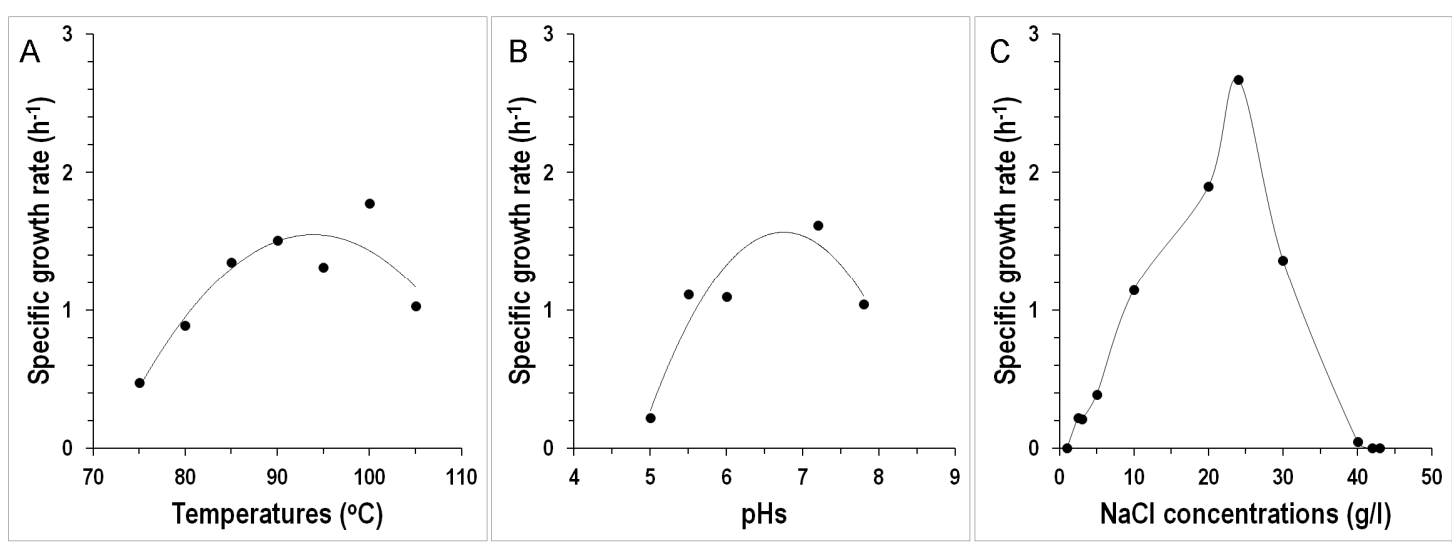

Figure 3. Conditions for the growth of strain PK 5017. A, Temperature. Cultures were grown in PT medium containing $10 \mathrm{~g} / 1 \mathrm{NaCl}, \mathrm{pH} 7.2$ and incubated at $75-105^{\circ} \mathrm{C}$. B, pHs. Cultures were grown in PT medium (24 g/l), $\mathrm{pH}$ range of 5-7.8 and incubated at $95^{\circ} \mathrm{C} . \mathrm{C}, \mathrm{NaCl}$ concentrations. Cultures were grown in PT medium containing 1-43 g/l NaCl, $\mathrm{pH} 7.2$ and incubated at $95^{\circ} \mathrm{C}$

\subsection{Comparative Growth Kinetics}

Growth rates at around the maximum and minimum limits of strain PK 5017 versus Pyrococcus furiosus and $P$. horikoshii were compared in this study. At $43 \mathrm{~g} / 1 \mathrm{NaCl}$, a negative $\mu$ value $\left(-0.003 \mathrm{~h}^{-1}\right)$ was determined on strain PK 5017. However, a $\mu$ value of $0.13 \mathrm{~h}^{-1}$ was obtained on P. furiosus. At $3 \mathrm{~g} / 1 \mathrm{NaCl}$, a $\mu$ value of $0.21 \mathrm{~h}^{-1}$ and a negative $\mu$ value $\left(-0.03 \mathrm{~h}^{-1}\right)$ were identified on strain PK 5017 and $P$. horikoshii, respectively (data not shown).

\subsection{Nutritional Requirements}

Growths of strain PK 5017 on pancreatic digest of casein, yeast extract, peptone, meat extract, beef extract and skim milk ( $5 \mathrm{~g} / \mathrm{l}$ ea.) were remarkably detected in the presence of $\mathrm{S}^{\mathrm{o}}$. Growths on maltose and trehalose, and slight growth on starch and xylitol were observed in $\mathrm{S}^{\mathrm{o}}$-free PT medium. No growth was detected on dextrose, sucrose, xylose, sorbitol, mannose and cellobiose (Table 1). 
Table 1. Characteristics of strain PK 5017 (this study), P. furiosus DSM 3638 (Fiala \& Stetter, 1986), P. horikoshii OT3 (González et al., 1998), and T. sibiricus MM 739 (Miroshnichenko et al., 2001)

\begin{tabular}{|c|c|c|c|c|}
\hline & $\begin{array}{l}\text { Pyrococcus sp. } \\
\text { strain PK } 5017^{\text {a }}\end{array}$ & $\begin{array}{c}P . \\
\text { furiosus }\end{array}$ & $\begin{array}{c}P . \\
\text { horikoshii } \\
\end{array}$ & $\begin{array}{c}T . \\
\text { sibiricus } \\
\end{array}$ \\
\hline \multicolumn{5}{|l|}{ Temperature range $\left({ }^{\circ} \mathrm{C}\right)$} \\
\hline Optimum & $95-100$ & 100 & 98 & 78 \\
\hline Range & $75-105$ & $70-103$ & $<80-102$ & $40-88$ \\
\hline \multicolumn{5}{|l|}{ pH } \\
\hline Optimum & 7.2 & 7 & 7 & 7.8 \\
\hline Range & $5->7.8$ & $5-9$ & $5-8$ & $5.8-9$ \\
\hline \multicolumn{5}{|l|}{$\mathrm{NaCl}(\mathrm{g} / \mathrm{l})$} \\
\hline Optimum & 24 & 20 & 24 & $18-20$ \\
\hline Range & $2.5-40$ & $5-50$ & $10-50$ & $5-70$ \\
\hline \multicolumn{5}{|l|}{ Growth on complex protein substrate ${ }^{b}$} \\
\hline $0.5 \mathrm{~g} / 1$ pancreatic digest of casein & \pm & $\pm^{\mathrm{a}}$ & $-^{\mathrm{a}}$ & $\mathrm{nr}$ \\
\hline $5 \mathrm{~g} / \mathrm{l}$ pancreatic digest of casein & + & $t^{\mathrm{a}}$ & $t^{\mathrm{a}}$ & + \\
\hline $\begin{array}{l}5 \mathrm{~g} / \mathrm{l} \text { peptone, yeast extract, beef extract, } \\
\text { meat extract or skim milk }\end{array}$ & + & + & + & + \\
\hline \multicolumn{5}{|l|}{ Growth on Carbohydrates ${ }^{\mathrm{b}}$} \\
\hline Dextrose & - & $\mathrm{-}^{\mathrm{a}}$ & - & - \\
\hline Maltose & + & $+^{\mathrm{a}}$ & $-{ }^{\mathrm{a}}$ & $\mathrm{nr}$ \\
\hline Trehalose & + & $\mathrm{nr}$ & $\mathrm{nr}$ & $\mathrm{nr}$ \\
\hline Xylitol & \pm & - & $\mathrm{nr}$ & $\mathrm{nr}$ \\
\hline Sucrose & - & - & - & $\mathrm{nr}$ \\
\hline Xylose & - & - & $\mathrm{nr}$ & $\mathrm{nr}$ \\
\hline Sorbitol & - & - & $\mathrm{nr}$ & $\mathrm{nr}$ \\
\hline Mannose & - & - & $\mathrm{nr}$ & $\mathrm{nr}$ \\
\hline Cellobiose & - & $\mathrm{nr}$ & - & $\mathrm{nr}$ \\
\hline Starch & \pm & + & - & - \\
\hline $\mathrm{G}+\mathrm{C}(\mathrm{mol} \%)$ & 42.5 & $40.8^{\mathrm{c}}$ & $41.9^{\mathrm{d}}$ & 38.4 \\
\hline Presence of Pyrococcus-like IS (IS-pfu) & Yes & Yes & No & $\mathrm{Yes}^{\mathrm{a}}$ \\
\hline Habitats & $\begin{array}{c}\text { Hot spring with } \\
\text { dissolved } \mathrm{Na}^{+} \text {and } \\
\mathrm{Cl}^{-} \text {ions }<1 \mathrm{~g} / 1\end{array}$ & Marine & Marine & $\begin{array}{l}\text { Oil reservoit } \\
\text { at a salinity } \\
\text { of } 24-52 \mathrm{~g} / 1\end{array}$ \\
\hline Depth (m) & $\begin{array}{c}>1,000 \text { above sea } \\
\text { level }\end{array}$ & 0 & 1395 & $\mathrm{nr}$ \\
\hline Origin & Northern Thailand & $\begin{array}{l}\text { Vulcano } \\
\text { Island }\end{array}$ & $\begin{array}{l}\text { Okinawa } \\
\text { Trough }\end{array}$ & $\begin{array}{l}\text { Western } \\
\text { Siberia }\end{array}$ \\
\hline
\end{tabular}

a determined in this study;

${ }^{\mathrm{b}}{ }_{-}=$no growth, $\pm=$slight growth or cell density between $10^{6}-10^{7}$ cells $/ \mathrm{ml},+=$ growth or cell density $>10^{7}$ cells $/ \mathrm{ml}, \mathrm{nr}=$ not reported;

c determined from the complete genome sequence (AE009950);

d determined from the complete genome sequence (NC_000961).

\subsection{Sulfur Metabolism}

Previous reports suggested that many species belonging to hyperthermophilic archaea in the Order Thermococcales required $S^{o}$ for their peptide fermentation (Fiala \& Stetter, 1986; Gonzalez et al., 1998; Adams, 1999.). To elucidate sulfur and sugar metabolisms of strain PK 5017, growths of strain PK 5017 and two archaeal references (P. furiosus and P. horikoshii) were conducted in 0.5 and $5 \mathrm{~g} / 1$ protein substrate. Results are shown in Figures 4A, 4B, 5A and 5B. The results obtained from the dilute protein substrate (LP medium) revealed growths of strain PK 5017 and P. furiosus, but not P. horikoshii, in the $\mathrm{S}^{\circ}$-containing media. No growth was observed in the $\mathrm{S}^{\circ}$-free medium and the maltose containing medium (Figures 4A and 4B). Average cell yields of $1.9 \times 10^{7}$ and $1.1 \times 10^{7}$ cells $/ \mathrm{ml}$ were obtained, respectively (Figure $4 \mathrm{~A}$ ). The results obtained from the HP 
medium (5 g/l pancreatic digest of casein) indicate substantial growths of strain PK 5017, P. furiosus and $P$. horikoshii (Figure 5A). An approximate 3 times increase in cell yields of strain PK 5017and P. furiosus were observed, compared with the growths in LP medium. A yield of 7.9 $10^{7}$ cells $/ \mathrm{ml}$ was determined on P. horikoshii growing under this condition (Figure 5A). Addition of maltose (2 and $5 \mathrm{~g} / \mathrm{l})$ to the HP medium did not remarkably increase cell densities of the tested hyperthermophiles (Figure 5A). On the other hand, cell densities of $P$. horikoshii ( 0.8 and 0.5 times of cell density at $0 \mathrm{~g} / 1$ maltose) were significantly inhibited by maltose ( 2 and $5 \mathrm{~g} / \mathrm{l})$ in the medium, respectively (p-value $<0.001$ ). The results suggest that growths on protein substrates of these archaea might require $S^{o}$. In Figure $5 B$, significant reduction of growth yields (0.04-0.1 times) were observed under $\mathrm{S}^{\circ}$-free condition, and the growths of strain PK 5017 and P. furiosus were substantially stimulated by amounts of maltose. However, $P$. horikoshii was unable to grow on maltose under this condition. The results confirmed that $\mathrm{S}^{\mathrm{o}}$ might not be an obligatory growth requirement for sugar metabolism of strain PK 5017.

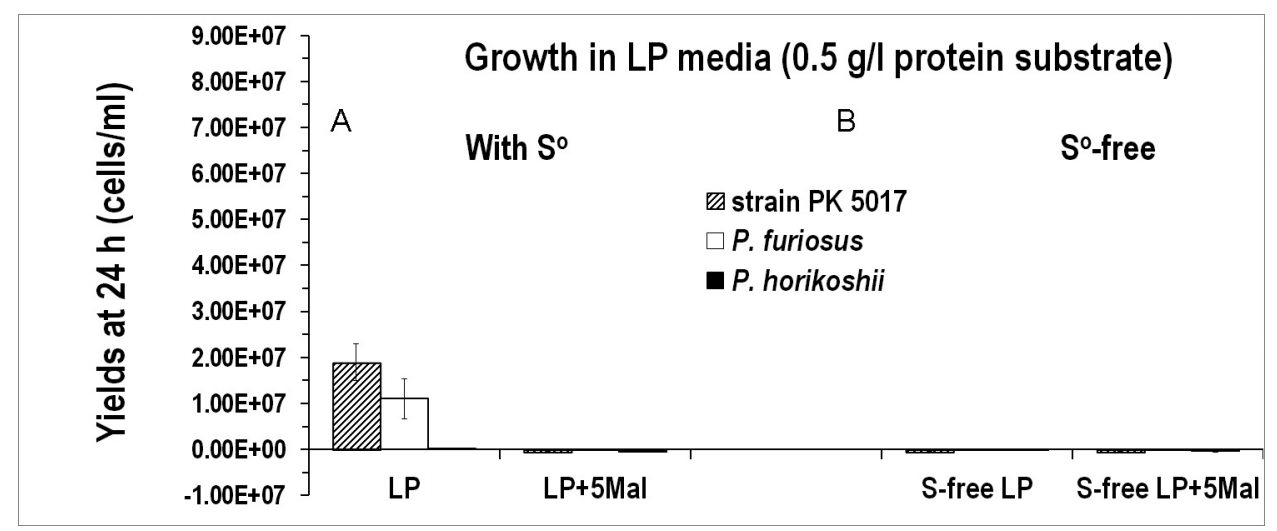

Figure 4. Effects of $\mathrm{S}^{\circ}$ on growth yields of strain PK 5017, Pyrococcus furiosus and Pyrococcus horikoshii tested in $0.5 \mathrm{~g} / \mathrm{l}$ pancreatic digest of casein (LP media, $\mathrm{pH} 7.2$ ) at $95^{\circ} \mathrm{C}$

A, Average growth yields obtained from the experiments conducted in the LP medium containing 0 or $5 \mathrm{~g} / 1$ maltose. B, Average growth yields obtained from the experiments conducted in $\mathrm{S}^{\mathrm{o}}$-free LP media containing 0 or $5 \mathrm{~g} / 1$ maltose. Symbols: Stripe box represents growth of strain PK 5017. White box represents growth of $P$. furiosus. Dark box represents growth of $P$. horikoshii. $5 \mathrm{Mal}$ stands for $5 \mathrm{~g} / 1$ maltose. Vertical bar on box indicates standard deviation $(\mathrm{n}=3)$.

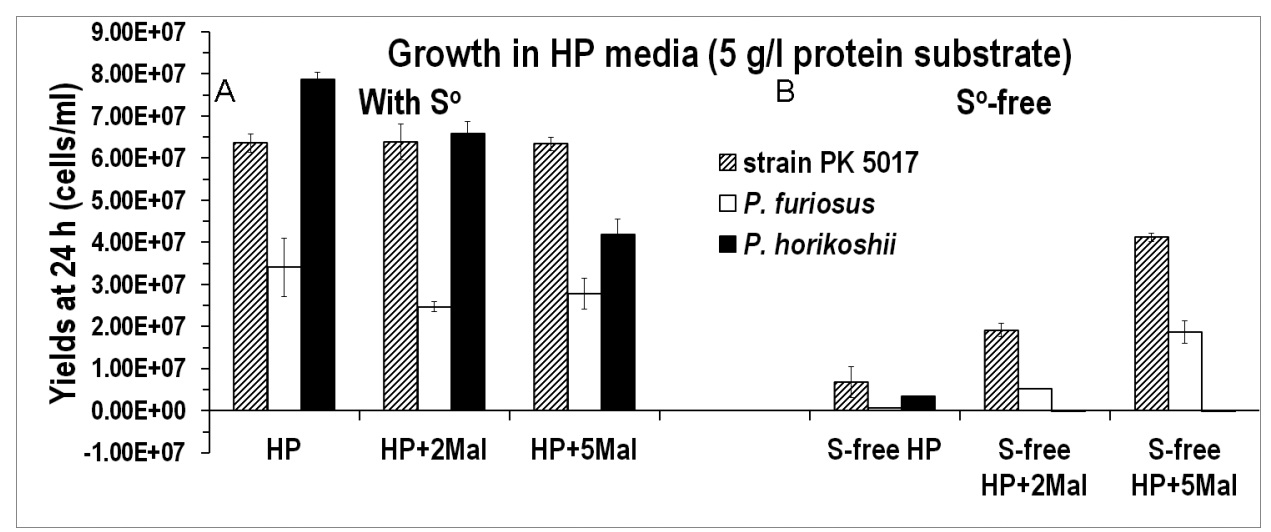

Figure 5. Effects of $\mathrm{S}^{\circ}$ on growth yields of strain PK 5017, Pyrococcus furiosus and Pyrococcus horikoshii tested in $5 \mathrm{~g} / 1$ pancreatic digest of casein ( $\mathrm{HP}$ medium, $\mathrm{pH} 7.2$ ) at $95^{\circ} \mathrm{C}$

A, Average growth yields obtained from experiments conducted in the HP medium containing 0,2 or $5 \mathrm{~g} / 1$ maltose. B, Average growth yields obtained from experiments conducted in $\mathrm{S}^{\circ}$-free HP media containing 0,2 or 5 g/l maltose. Symbols: Stripe box represents growth of strain PK 5017. White box represents growth of $P$. furiosus. Dark box represents growth of $P$. horikoshii. $2 \mathrm{Mal}$ and $5 \mathrm{Mal}$ stand for 2 and $5 \mathrm{~g} / \mathrm{l}$ maltose, respectively. 
Vertical bar on box indicates standard deviation $(\mathrm{n}=3)$.

\subsection{Detection of the IS-pfu and Phylogenetic Analysis}

The transposition event by an IS-pfu-III disrupting the napA gene of P. furiosus subsp. woesei (GenBank AF461062) provided an evidence on strain differentiation between two closely related $P$. furiosus, isolated from Vulcano Island, Italy (Kanoksilapatham et al., 2004). In order to identify the IS-pfu sequences in the genome of strain PK 5017, PCR amplification using a primer specific to the IR sequences of the IS-pfus was conducted. A predicted size of $780 \mathrm{nt}$. long PCR product was successfully amplified. No specific PCR product was detected in P. horikoshii, isolated from Okinawa Trough, North Pacific Ocean (data not shown). Sequencing results of the cloned PCR products and phylogenetic analysis revealed 4 copies of the IS-pfu-I (GenBank JF818120-JF818123) and a copy of IS-pfu-III (JF818124) (Figure 6). Structures of the homologous IS-pfu types I, II and III in $P$. furiosus were previously described (Kanoksilapatham et al., 2004). Figure 7A shows structures of the IS-pfu-I (JF818120) and IS-pfu-III (JF818124) in strain PK 5017 and their related sequences. The types I and III in strain PK 5017 consists of a 54-57 nt. long spacer, a putative transposase (tnp) gene flanked by a pair of $16 \mathrm{nt}$. long IRs similar to the prototypes IS-pfu-I and IS-pfu-III in P. furiosus, respectively (Figures 7A-7C). Alignment results revealed that the JF818120-JF818122 contained an amino acid substitution at $A^{53} T, E^{93} \mathrm{~K}$ and $G^{123} \mathrm{D}$, respectively (no. $1=$ the first $\mathrm{M}$ of the Tnp), but not the JF818123. The JF818124 contains four nucleotide substitutions at $\mathrm{G}^{136} \mathrm{~A}, \mathrm{~T}^{690} \mathrm{C}, \mathrm{T}^{699} \mathrm{G}$ and $\mathrm{G}^{712} \mathrm{~A}$ (no.1 = the first nucleotide of JF818124) compared with the type III sequence in P. furiosus (AE009950: nt. nos. 771322-772100). The homologous IS-pfus in the genome of strain PK 5017 suggests that strain PK 5017 and those Mediterranean Sea Pyrococcus spp. isolates might share a common ancestor.

\subsection{Identification of Pfu-like IS Elements in Thermococcus Sibiricus MM 739}

Results of blast search using discontinuous megablast algorithm revealed two deletion copies of IS-pfu homologs (74 and $79 \%$ similarity to the IS-pfu-I) in the complete genome sequence of T. sibiricus MM 739 (GenBank CP001463: nt. nos. 1081098-1081847 and 1776235-1776671). The 750 (nt. nos. 1081098-1081847) and 437 (nt. nos. 1776235-1776671) nt. long DNA fragments were named "IS-pfu-Ts1" and "IS-pfu-Ts2" in this study, respectively. Phylogenetic analysis positioned IS-pfu-Ts1 in a separate lineage from the prototype type I, and IS-pfu-Ts2 in a deeper branch than the prototypes types II and III, respectively (Figure 6).

The IS-pfu-Ts1 comprises a $55 \mathrm{nt}$. long spacer and a truncated tnp gene homolog (663 nt. long) flanked by $16 \mathrm{nt}$. long IR sequences (5' GATACTGTCGGGATAA 3'/ 5' TTATCCTGACAGTATC 3'); and the IS-pfu-Ts2 comprises a $15 \mathrm{nt}$. long 5'-end IR (5' GATACTGTCAGGTGA 3'), a $57 \mathrm{nt}$. long spacer and a truncated tnp gene homolog (365 nt. long), but lacks the 3'-end IR (Figure 7A). Alignments of the IR sequences (Figure 7B) and the spacer regions (Figure 7C) revealed substantial similarity to the sequences reported in P. furiosus. The results imply that IS-pfu-Ts1 and IS-pfu-Ts2 present in genome of the subterranean isolate are homologs of the repetitive elements in the marine $P$. furiosus.

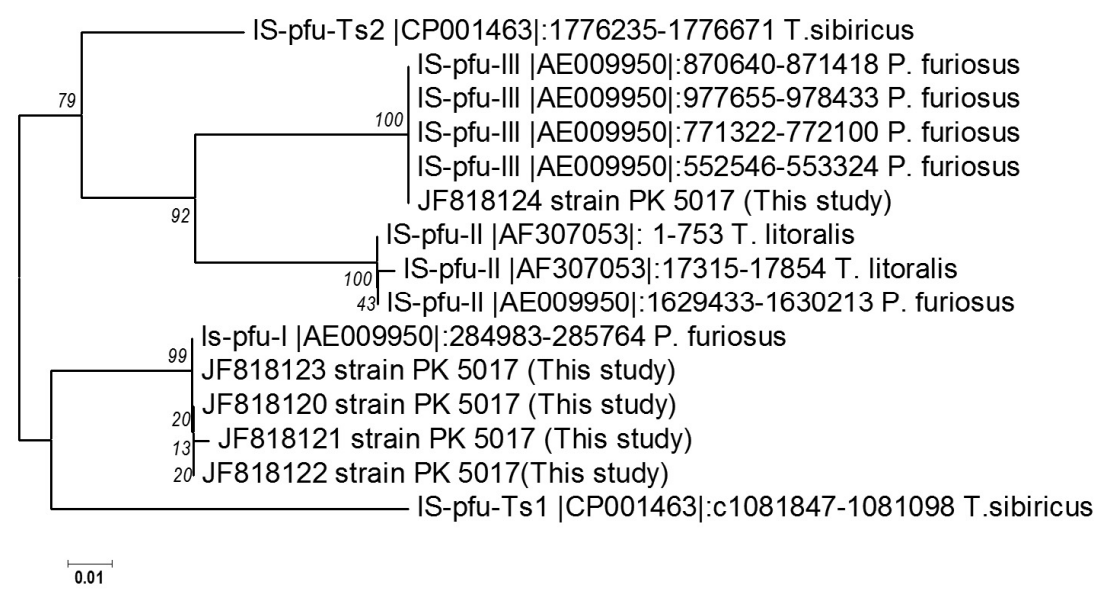

Figure 6. Unrooted phylogenetic tree of insertion sequences in genomes of strain PK 5017, Pyrococcus furiosus DSM 3638, Thermococcus litoralis and Thermococcus sibiricus MM 739 inferred by Neighbor joining algorithm

Alignment was performed by using CLUSTAL W. Pairwise distances were computed from a bootstrap score of 
1000 using the program MEGA 5.05. Nucleotide sequences of prototypes IS-pfus-I, -II and -III in P. furiosus DSM 3638 were from GenBank AE009950, and the truncated IS-pfu-II in T. litoralis were from GenBank AF307053. IS-pfu-Ts1 and -Ts2 homologs were identified in T. sibiricus MM 739 (CP001463) in this study.

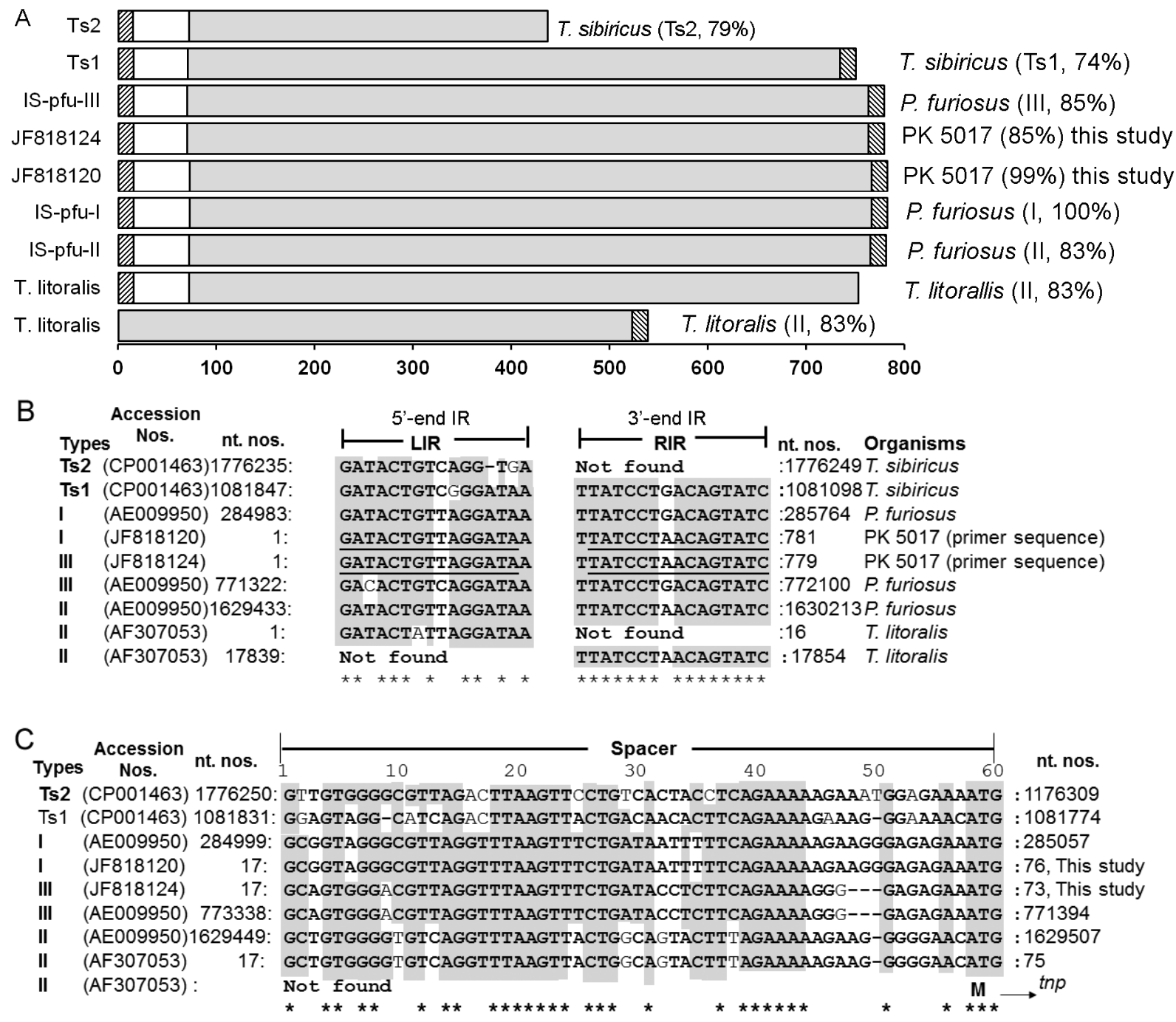

Figure 7. Comparisons of structures and sequences of IS-pfu and pfu-like IS of elements

A, Diagramatic structures of the IS-pfus and pfu-like IS homologs (Ts1 and Ts2). Stripe boxes represent inverted repeats. White boxes represent spacers between the 5 '-end IR and putative transposase (tnp) gene. Grey boxes represent the putative tnp homologs. Percentage similarity to IS-pfu-I was indicated in parenthesis. Scale indicates nucleotide numbers. B, Alignment of 5'-end and 3'-end inverted repeat sequences (LIR and RIR, respectively). Bold letters and grey color represent consensus nucleotides. Asterisks represent identical nucleotides. Dashes indicate missing nucleotides. Underline indicates nucleotide sequence of primer (5' GATAC TGTTA GGATA 3') employed to amplify the IS-pfus from strain PK 5017. White color indicates different nucleotide. C, Alignment of spacer sequences. Bold letters and grey color represent consensus nucleotides. Asterisks represent identical nucleotides. Dashes indicate missing nucleotides. White color indicates different nucleotides.

\section{Discussion}

Strain PK 5017 was isolated from sediment collected from Pong Duet Hot Spring in Huai Nam Dang National Park $\left(19^{\circ} 14^{\prime} \mathrm{N}, 98^{\circ} 41^{\prime} \mathrm{E}\right)$, Northern Thailand. Based on $16 S$ rRNA gene sequences and phylogenetic analysis (Figure 2), strain PK 5017 is identified as a Pyrococcus sp. 
Based on the optimal growth condition $\left(95-100{ }^{\circ} \mathrm{C}, \mathrm{pH} 7.2,24 \mathrm{~g} / 1 \mathrm{NaCl}\right)$, strain PK 5017 is similar to $P$. furiosus and P. horikoshii (Table 1). Growth rates compared in this study at $43 \mathrm{~g} / \mathrm{l} \mathrm{NaCl}$, strain PK $5017\left(\mu=-0.003 \mathrm{~h}^{-1}\right)$ was differentiated from P. furiosus $\left(\mu=0.13 \mathrm{~h}^{-1}\right)$; and at $3 \mathrm{~g} / 1 \mathrm{NaCl}$, strain PK $5017\left(\mu=0.21 \mathrm{~h}^{-1}\right)$ was differentiated from $P$. horikoshii $\left(\mu=-0.032 \mathrm{~h}^{-1}\right)$.

Like most hyperthermophiles belonging to the Order Thermococcales, strain PK 5017 ferments peptide substrates in the presence of $\mathrm{S}^{\circ}$ (Figures 5A and 5B) (Fiala and Stetter, 1986; Jannasch et al., 1992; Gonzalez et al., 1998; Barbier et al., 1999; Miroshnichenko et al., 2001). Strain PK 5017 utilizes maltose, trehalose, starch and xylitol, but not dextrose, sucrose, xylose, sorbitol, mannose and cellobiose. Like other archaea belonging to the Order Thermococcales, strain PK 5017 does not utilize dextrose (Fiala \& Stetter, 1986; Gonzalez et al., 1998; Miroshnichenko et al., 2001). Ability to utilize maltose of P. furiosus and P. horikoshii was confirmed in this study (Figure 5B and Table 1). Like P. furiosus, strain PK 5017 utilizes maltose as carbon and energy source in $\mathrm{S}^{\mathrm{o}}$-free media. Previously, an inducible malEFG operon responsible for uptaking maltose and trehalose in $P$. furiosus was found to be associated with the IS-pfu-II composite Tn (DiRuggiero et al., 2001). The malEFG operon homolog was revealed missing in $P$. horikoshii (Maeder et al., 1999), corresponding to the failure of $P$. horikoshii to grow on maltose (Figure 5B). Like P. furiosus, strain PK 5017 is able to grow in dilute peptide substrate ( $0.5 \mathrm{~g} / 1$ pancreatic digest of casein), distinct from $P$. horikoshii (Figure 4A).

Although the DNA-DNA hybridization experiments revealed closer relatedness of strain PK 5017 to $P$. horikoshii (78 \% similarity) than P. furiosus (44\% similarity), genome of strain PK 5017 contains several copies of the homologous IS-pfu-I (JF818120-JF818123) and IS-pfu-III (JF818124) similar to P. furiosus. Previous reports suggested that the genomes of $P$. furiosus and other related Mediterranean Sea isolates contained multiple copies of the active IS-pfus (Kanoksilapatham et al., 2004; Escobar-Páramo et al., 2005). The nucleotide substitutions detected in the IS-pfu sequences (JF818120-JF818122 and JF818124) indicate that strain PK 5017 and $P$. furiosus might have evolved from a common ancestor or have had the opportunity for genetic exchange events previous to their geographical isolation.

The presence of IS-pfu homolog has never been disclosed in the complete genome of T. sibiricus MM 739, a Siberia isolate (Miroshnichenko et al., 2001). In this study, two homologs of the homologous IS-pfu (named "IS-pfu-Ts1" and "IS-pfu-Ts2") were identified in T. sibiricus MM 739 based on the sequence similarities (Figures 6 and 7A-C). Phylogenetic analysis reveals the truncated IS-pfus-Ts1 and IS-pfu-Ts2 in deeper branches than the prototypes, implying their co-existence at some point in time of primitive elements in the genome of the Siberia isolate.

\section{Conclusion}

A strictly anaerobic, heterotrophic strain PK 5017 is identified as a member of Pyrococcus sp. based on morphological, biochemical, physiological and DNA characteristics. The genomic DNA-DNA hybridization results and the presence of nucleotide substitutions detected in the IS-pfu-I and IS-pfu-III of strain PK 5017 are crucial evidences supporting differential genome sequence from $P$. furiosus. On the other hand, strain PK 5017 is more closely related to $P$. horikoshii than P. furiosus based on DNA-DNA hybridization techniques (78\% similarity to $P$. horikoshii and $44 \%$ similarity to $P$. furiosus). Unique characteristics of strain PK 5017 compared with the others are listed as follows: a freshwater isolate, ability to grow at a lower range of $\mathrm{NaCl}$ concentration $(2.5-<40 \mathrm{~g} / \mathrm{l})$, ability to grow on xylitol in $\mathrm{S}^{\mathrm{o}}$-free medium (Table 1) and a different $\mathrm{G}+\mathrm{C}$ content $(42.5 \mathrm{~mol} \%)$. Therefore, strain PK 5017 is distinct from P. furiosus and P. horikoshii. Pyrococcus sp. strain PK $5017=$ Pyrococcus sp. strain Pikanate $5017=$ JCM17043 = ATCC BAA-2246.

\subsection{Description of Pyrococcus sp. Strain PK 5017}

Strain PK 5017 is a strictly anaerobic, heterotrophic, hyperthermophilic Pyrococcus sp., which was isolated from a freshwater hot spring in Northern Thailand. Cells of strain PK 5017 are irregular cocci occurring singly and in pairs with a diameter range of 0.7-1.2 $\mu \mathrm{m}$. Temperature, $\mathrm{pH}$ and $\mathrm{NaCl}$ concentration ranges for growth are 75-105 ${ }^{\circ} \mathrm{C}$ (opt. temp. $=95-100{ }^{\circ} \mathrm{C}$ ), $\mathrm{pH} 5-7.8$ (opt. $\mathrm{pH}=7.2$ ) and $2.5-<40 \mathrm{~g} / 1 \mathrm{NaCl}$. (opt. conc. $=24 \mathrm{~g} / \mathrm{l}$ ). Growth on pancreatic digest of casein, yeast extract, peptone, meat extract, beef extract and skim milk ( $5 \mathrm{~g} / \mathrm{l}$ ea.) occurs in $\mathrm{S}^{\mathrm{o}}$-containing media. Slight growth on dilute pancreatic digest of casein $(0.5 \mathrm{~g} / \mathrm{l})$ occurs in the presence of $\mathrm{S}^{\mathrm{o}}$. Elemental sulfur is not obligatory for growth, but stimulates growth. Growth on maltose, trehalose, starch and xylitol occurs in $\mathrm{S}^{\mathrm{o}}$-free media. No growth occurs on dextrose, sucrose, xylose, sorbitol, mannose and cellobiose. $\mathrm{G}+\mathrm{C}$ content of genome of strain PK 5017 is $42.5 \mathrm{~mol} \%$. Genome of strain PK 5017 contains multiple copies of the homologous IS-pfu of elements. Pyrococcus sp. strain PK $5017=$ Pyrococcus sp. strain Pikanate $5017=$ JCM17043 = ATCC BAA-2246.

\section{Acknowledgements}


This work was supported by the Scientific Promotion and Development Fund, Faculty of Science, Silpakorn University (RGI 2553-06) and Silpakorn University Research and Development Institute (SURDI 54/01/18 and SURDI 55/01/05). JMG and MCP acknowledge support from a CSIC movility program, PA1001993 and PA1002058, and the Andalusian Government Bio288 which included FEDER funds. We thank Frank T. Robb (Institute of Marine and Environmental Technology, Maryland) for his collaboration.

\section{References}

Adams, M. W. W. (1999). The biochemical diversity of life near and above $100^{\circ} \mathrm{C}$ in marine enviroments. J. Appl. Microbiol. Symp. Suppl., 85, 108S-117S.

Adams, M. W. W., Holden, J. F., Menon, A. L., Schut, G. J., Grunden, A. M., Hou, C., .. Verhagen, M. F. J. M. (2001). Key role for sulfur in peptide metabolism and in regulation of three hydrogenases in the hyperthermophilic archaeon Pyrococcus furiosus. J. Bacteriol., 183, 716-724. http://dx.doi.org/10.1128/JB.183.2.716-724.2001

Barbier, G., Godfroy, A., Meunier, J. R., Quérellou, J., Cambon, M. A., Lesongeur, F., Grimont, P. A., \& Raguénès, G. (1999). Pyrococcus glycovorans sp. nov., a hyperthermophilic archaeon isolated from the East Pacific Rise. Int. J. Syst. Bacteriol., 49, 1829-1837. http://dx.doi.org/10.1099/00207713-49-4-1829

Birrien, J. L., Zeng, X., Jebbar, M., Cambon-Bonavita, M. A., Quérellou, J., Oger, P., Bienvenu, N., Xiao, X., \& Prieur, D. (2011). Pyrococcus yayanosii sp. nov., an obligate piezophilic hyperthermophilic archaeon isolated from a deep-sea hydrothermal vent. Int. J. Syst. Evol. Microbiol., 61(Pt 12), 2827-2831. http://dx.doi.org/10.1099/ijs.0.024653-0

Cambon-Bonavita, M. A., Lesongeur, F., Pignet, P., Wery, N., Lambert, C., Godfroy, A., Querellou, J., \& Barbier, G. (2003). Extremophiles, Thermophily section, species description Thermococcus atlanticus sp. nov., a hyperthermophilic Archaeon isolated from a deep-sea hydrothermal vent in the Mid-Atlantic Ridge. Extremophiles, 7, 101-109. http://dx.doi.org/10.1007/s00792-003-0343-6

Charbonnier, F., \& Forterre, P. (1995). Purification of plasmids from thermophilic and hyperthermophilic archaea. In: F. T. Robb, \& A. R. Place (Eds.) Archaea, a laboratory manual. Thermophiles, pp. 87-90. Cold Spring Harbor Laboratory, Cold Spring Harbor, NY.

DeLong, E. F. (1992). Archaea in coastal marine environments. Proc. Natl. Acad. Sci. USA, 89(12), 5685-5689.

DiRuggiero, J., Dunn, D., Maeder, D. L., Holley-Shanks, R., Chatard, J., Horlacher, R., ... Weiss, R. B. (2000). Evidence of recent lateral gene transfer among hyperthermophilic archaea. Mol. Microbiol., 38, 684-693. http://dx.doi.org/10.1046/j.1365-2958.2000.02161.x

Erauso, G., Reysenbach, A. L., Godfroy, A., Meunier, J. R., Crump, B., Partensky, F., ... Prieur, D. (1993). Pyrococcus abyssi sp. nov., a new hyperthermophilic archaeon isolated from a deep-sea hydrothermal vent. Arch. Microbiol., 160, 338-349. http://dx.doi.org/10.1007/BF00252219

Escobar-Páramo, P., Ghosh, S., \& DiRuggiero, J. (2005). Evidence for genetic drift in the diversification of a geographically isolated population of the hyperthermophilic archaeon Pyrococcus. Mol. Biol. Evol., 22, 2297-2303. http://dx.doi.org/10.1093/molbev/msi227

Fiala, G., \& Stetter, K. O. (1986). Pyrococcus furiosus sp. nov. represents a novel genus of marine heterotrophic archaebacteria growing optimally at $100{ }^{\circ} \mathrm{C}$. Arch. Microbiol., 145, 56-61. http://dx.doi.org/10.1007/BF00413027

Gonzalez, J. M., Masuchi, Y., Robb, F. T., Ammerman, W., Maeder, D. L., Yanagibayashi, M., ... \& Kato, C. (1998). Pyrococcus horikoshii sp. nov., a hyperthermophilic archaeon isolated from a hydrothermal vent at the Okinawa Trough. Extremophiles, 2, 123-130. http://dx.doi.org/10.1007/s007920050051

Gonzalez, J. M., Sheckells, D., Vareike, M., Kupratkina, D., Borges, K., \& Robb, F. T. (1999). Thermococcus waiotapuensis sp. nov., a hyperthermophilic archaeon from freshwater hot springs in New Zealand. Arch. Microbiol., 172, 95-101. http://dx.doi.org/10.1007/s002030050745

Huber, R., Stöhr, J., Honenhaus, S., Rachel, R., Burggraf, S., Jannash, H. W., \& Stetter, K. O. (1995). Thermococcus chitonophagus sp. nov., a novel, chitin-degrading, hyperthermophilic archaeum from a deep-sea hydrothermal vent. Arch. Microbiol., 164, 255-264. http://dx.doi.org/10.1007/s002030050262

Jannasch H. W., Wirsen, C. O., Molyneux, S. J., \& Langworthy, T. A. (1992). Comparative physiological studies on hyperthermophilic archaea isolated from deep-sea hot vents with emphasis on Pyrococcus strain GB-D. Appl. Environ. Microbiol., 58, 3472-3481. 
Kanoksilapatham, W., González, J. M., Maeder, D. L., DiRuggiero, J., \& Robb, F. T. (2004). A proposal to rename the hyperthermophile Pyrococcus woesei as Pyrococcus furiosus, sub sp. woesei. Archaea, 1, 277-283. http://dx.doi.org/10.1155/2004/513563

Kecha, M., Benallaoua, S., Touzel, J. P., Bonaly, R., \& Duchiron, F. (2007). Biochemical and phylogenetic characterization of a novel terrestrial hyperthermophilic archaeon pertaining to the genus Pyrococcus from an Algerian hydrothermal hot spring. Extremophiles, 11(1), 65-73. http://dx.doi.org/ 10.1007/s00792-006-0010-9

Kobayashi, T., Kwak, Y. S., Akiba, T., Kudo, T., \& Horikoshi, K. (1994). Thermococcus profundus sp. nov., a new hyperthermophilic archaeum isolated from a deep-sea hydrohermal vent. Syst. Appl. Microbiol., 17, 232-236. http://dx.doi.org/10.1016/S0723-2020(11)80013-5

Maeder, D. L., Weiss, R. B., Dunn, D. M., Cherry, J. L., González, J. M., DiRuggiero, J., \& Robb, F. T. (1999). Divergence of the hyperthermophilic archaea Pyrococcus furiosus and P. horikoshii inferred from complete genomic sequences. Genetics, 152, 1299-1305.

Marmur, J., \& Doty, P. (1962). Determination of the base composition of deoxyribonucleic acid from its thermal denaturation temperature. J. Mol. Biol., 5, 109-118. http://dx.doi.org/10.1016/S0022-2836(62)80066-7

Miroshnichenko, M. L., Gongadze, G. M., Rainey, F. A., Kostyukova, A. S., Lysenko, A. M., Chernyh, N. A., \& Bonch-Osmolovskaya, E. A. (1998). Thermococcus gorgonarius sp. nov. and Thermococcus pacificus sp. nov.: heterotrophic extremely thermophilic archaea from New Zealand submarine hot vents. Int. J. Syst. Bacteriol., 48 Pt 1, 23-29. http://dx.doi.org/10.1099/00207713-48-1-23

Miroshnichenko, M. L., Hippe, H., Stackebrandt, E., Kostrikina, N. A., Chernyh, N. A., Jeanthon, C., Nazina, T. N., Belyyaev, S. S., \& Bonch-Osmolovskaya, E. A. (2001). Isolation and characterization of Thermococcus sibiricus sp. nov. from a Western Siberia high-temperature oil reservoir. Extremophiles, 5, 85-91. http://dx.doi.org/10.1007/s007920100175

Neuner, A., Jannasch, H. W., Belkin, S., \& Stetter, K. O. (1990). Thermococcus litoralis sp. nov., a new species of extremely thermophilic marine archaebacteria. Arch. Microbiol., 153, 205-207. http://dx.doi.org/10.1007/BF00247822

Pikuta, E. V., Marsic, D., Itoh, T., Bej, A. K., Tang, J., Whitman, W. B., ... R. B. (2007). Thermococcus thioreducens sp. nov., a novel hyperthermophilic, obligately sulfur-reducing archaeon from a deep-sea hydrothermal vent. Int. J. Syst. Evol. Microbiol., 57, 1612-1618. http://dx.doi.org/10.1099/ijs.0.65057-0

Ronimus, R. S., Reysenbach, A-L., Musgrave, D. R., \& Morgan, H. W. (1997). The phylogenetic position of the Thermococcus isolate AN1 based on $16 \mathrm{~S} r R N A$ gene sequence analysis: a proposal that AN1 represents a new species, Thermococcus zilligii sp. nov. Arch. Microbiol., 168, 245-248. http://dx.doi.org/10.1007/s002030050495

Stetter, K. O. (1996). Hyperthermophilic prokaryotes. FEMS Microbiol. Rev., 18, 149-158.

Tamura, K., Peterson, D., Peterson, N., Stecher, G., Nei, M., \& Kumar, S. (2011). MEGA5: molecular evolutionary genetics analysis using maximum likelihood, evolutionary distance, and maximum parsimony methods. Mol. Biol. Evol., 28(10), 2731-2739. http://dx.doi.org/10.1093/molbev/msr121

Thompson, J. D., Higgins, D. G., \& Gibson, T. J. (1994). The CLUSTAL W: improving the sensitivity of progressive multiple sequence alignment through sequence weighting, position-specific gap penalties and weight matrix choice. Nucleic Acids Res., 22, 4673-4680. http://dx.doi.org/10.1093/nar/22.22.4673

White, J. R., Escobar-Paramo, P., Mongodin, E. F., Nelson, K. E., \& DiRuggiero, J. (2008). Extensive genome rearrangements and multiple horizontal gene transfers in a population of pyrococcus isolates from Vulcano $\begin{array}{llll}\text { Island, Italy. Appl. Environ. Microbiol., } & \text { 74(20), }\end{array}$ http://dx.doi.org/10.1046/j.1462-2920.2003.00533.x

Woese, C. R., Kandler, O., \& Wheelis, M. L. (1990). Towards a natural system of organisms: proposal for the domains Archaea, Bacteria, and Eucarya. Proc. Natl. Acad. Sci. USA, 87, 4576-4579.

Ziemke, F., Höfle, M. G., Lalucat, J., \& Roselló-Mora, R. (1998). Reclassification of Shewanella putrefaciens Owen's genomic group II as Shewanella baltica sp. nov.. Int. J. Syst. Bacteriol., 48, 179-186. http://dx.doi.org/ 10.1099/00207713-48-1-179

Zillig, W., Holz, I., Klenk, H-P., Trent, J., Wunderl, S. Janekovic, D., Imsel, E., \& Haas, B. (1987). Pyrococcus woesei sp. nov., an ultra-Thermophilic marine archaebacterium, representing a novel order, Thermococcales. Syst. Appl. Microbiol., 9, 62-70. http://dx.doi.org/10.1016/S0723-2020(87)80057-7 